SUWITO: Relasi Cinta...

\title{
RELASI CINTA DALAM TASAWUF
}

\author{
Suwito \\ Sekolah Tinggi Agama Islam Negeri (STAIN) Purwokerto, Jawa \\ Tengah \\ e-mail: suwitons@gmail.com
}

\begin{abstract}
This article discusses the relationship of love in the Sufi perspective. Opositorum Coindencia theory is used to dissect this relationSip, so that the devil Sufism is seen as a "sparring partner" in human spiritual quality improvement activities. This article shows that the Sufi tradition mainly in Wahdah al-Wujūd, using imaginal thinking mindset see and understand the duality (bipolar), even though this diversity is unity of opposites. In the context of Sufi, masculinity-whichstated that the dominant sociological-declared substantially have "weaknesses." Because masculinity will not appear if there is no femininity. While in the context of the birth of the universe and the form of anything that is in fact born out of the urge of love that goes on this feminine category. In other words, masculinity will not be born if it is not driven by the feminine aspect. This is the "mystery of immense power" aspect of femininity in Sufi discourse. Thus, there is nothing more superiority between these two aspects. Relation is equal based on and effect of love.
\end{abstract}

Abstrak: Artikel ini membahas tentang relasi cinta dalam perspektif Sufi. Teori Coindencia Opositorum dipakai untuk membedah relasi ini, sehingga dalam Sufisme setan dipandang sebagai "sparing partner" manusia dalam melakukan kegiatan peningkatan kualitas ruhani. Artikel ini menunjukkan bahwa tradisi sufi terutama dalam tasawuf wahdat al-wujūd, dengan menggunakan pola pikir imaginal thinking melihat dan memahami dualitas (bipolar), bahkan keragaman sekalipun ini adalah unity of opposites. Dalam konteks sufi, maskulinitasyang dinyatakan yang secara sosiologis dinyatakan dominan itu - secara substansial memiliki "kelemahan". Karena maskulinitas tidak akan muncul jika tidak ada femininitas. Sementara dalam konteks lahirnya wujud semesta dan apapun yang ada justru lahir karena dorongan cinta yang masuk pada kategori feminin ini. Dengan kata lain, maskulinitas tidak akan lahir jika tidak didorong oleh aspek feminin. Inilah "misteri

TEOLOGIA, VOLUME 25, NOMOR 2, JULI-DESEMBER 2013 
SUWITO: Relasi Cinta...

kekuatan dahsyat" aspek femininitas dalam wacana sufi. Dengan demikian, tidak ada yang lebih superioritas antara dua aspek ini.Relasinya adalah setara berdasar dan akibat dari cinta.

Keywords: Waḥdah al-Wujūd, sufi, feminitas, maskulinitas, hubb.

\section{A. Pendahuluan}

Cinta $(h u b b)$ adalah salah satu tema penting dalam sufi.Dalam alQuran, hubbyang kemudian menjadi pembahasan penting dalam tasawuf paling tidak disebut pada beberapa ayat seperti QS. 5:54,1 dan beberapa hadis. ${ }^{2}$ Pembicaraan tentang cinta sering kali dikaitkan dan dipahami sebagai, 1) station (maqāmāt) tahapan sufi, 2) keadaan jiwa (state of soul), ${ }^{3} 3$ ) alasan keberadaan kosmos. ${ }^{4}$

Dalam literatur sufi, konsep cinta seringkali dihubungkan dengan Rābi'ah al-'Adawiyah (w.801), ${ }^{5}$ walaupun kemudian tema ini kemudian berkembang di berbagai tulisan tentang kehidupan sufi seperti al-Ghazālī (w.1111), Ibn 'Arabī (w.1240), Rūmī (w.1273),' dan penulis-penulis setelahnya. Hal ini karena, Rabi'ah dalam beberapa syairnya menggunakan $\underline{h} u b b$ (cinta) ini menjadi kata kuncinya, demikian juga Rūmī dalam puisi-puisinya.

Bagi Rūmī, cinta-sebagaidimensi pengalaman rohani-sepenuhnya "mengendalikan" keadaan batin dan psikologis sufi. Baginya, cinta benar-benar tidak dapat diungkapkan melalui katakata.7 Dengan kata lain, kata-kata tidak dapat menampung hasrat cinta yang sesungguhnya. Cinta berada di seberang pemikiran, tetapi dia ada pada dalam pengalaman yang lebih nyata dari pada dunia dan segala yang ada di dalamnya.

Dalam makalah ini, akan dibahas relasi cinta antara Tuhan dan kosmos dalam tasawuf. Pembahasan ini sudah barang tentu akan bersinggungan dengan konsep-konsep yang "berlawanan" dengan makna cinta. Untuk membahas dua hal yang sepertinya bertentanga itu, maka unity of opposites (kesatuan dari kontradiksi-kondraksi) atau coincedentia oppositorumakan ditampilkan di bagian awal pembahasan ini. 
SUWITO: Relasi Cinta...

\section{B. Coincedentia Oppositorum: Sebuah Perspektif}

Coincedentia Oppositorum ataunnity of opposites (al-jam'u bain al-'addād) adalah istilah yang dikenalkan oleh filosof Yunani praskolastik Heraclitus (535-475 SM). ${ }^{8}$ Coincidentia oppositorum adalah frase dari bahasa Latin yang berarti coincidenceopposites atau kesatuan antara kontradiksi-kontradiksi.

Ini adalah terma neoplatonic yang dinisbahkan pada ahli matematika German Nicholas of Cusa in his essay, De Docta Ignorantia (1440). Mircea Eliade, sejarawan agama pada abad ke 20 menggunakan istilah ini secara lebih luas pada essainya tentang mitologi dan ritual. Demikian juga ahli psikiatri Carl Jung, Henry Corbin (filosof dan ahli Islamic Studies), juga GerȘom Scholem (filosof Yahudi).Term ini juga digunakan untuk menjelaskan wahyu tentang "kemanunggalan" sesuatu yang sebelumnya diyakini berbeda.

Unity of opposites adalah konsep sentral dalam dialektika, baik dalam mistisisme, filsafat, maupun sain. Konsep ini dapat didefiniskan sebagai situasi atau identitas yang melingkupi eksistensi (wujud). Walaupun, situasi dan identitas wujud ini sangat tergantu pada ko-eksisten. Situasi dan identitas yang dipengaruhi oleh koeksisten ini yang menjadikan dia berbeda (opposite) dengan yang lainnya. Dalam tataran wujud eksisten, sifat beda memang harus ada, agar wujud dapat dibedakan.

Dalam logika formal dan ilmu matematika mengatakan bahwa kesatuan (unity) tidak mungkin ada, tetapi penganut dialektika mengklaim bahwa unity bisa dalam realitas atau dalam pikiran. Jika yang berlawanan itu seimbang, maka yang hasilnya adalah statis, namun jika salah satu yang berlawanan tersebut lebih kuat atau lebih dominan, maka yang terjadi satu posisi mengalahkan posisi yang lain. ${ }^{9}$

Jika dikaitkan dengan model pemikiran yang ada selama ini, maka dapat disebut bahwa model rasionalisme telah lama

TEOLOGIA, VOLUME 25, NOMOR 2, JULI-DESEMBER 2013 
SUWITO: Relasi Cinta...

berkembang di Barat. Spirit Averrosm di Barat mendapat tempat setelah disistematisir oleh Descartes. Pola Cartesian-sebagaimana Noer-mewakili satu kutub kontinum rational thinking, sebagai oposisi dari imaginal thinking. ${ }^{10}$

Rational thinking sebagaimana logika formal dan matematika tidak mengenal unity on opposite, karena keberadaan angka 2 karena ada -2, yang keduanya tidak dapat disatukan. Dengan demikian, pola pikir ini tampak hitam atau putih, ini atau itu (either...or...). Di sisi lain, imaginal thinking secara paradigmatik memungkinkan adanya penyatuan (unity) dari sesuatu yang berlawanan (opposites).

Dalam tulisan ini, kerangkan coincidentia oppositorum yang masuk pada wilayah cara berfikir imaginal (imaginal thinking) akan digunakan untuk melihat nama-nama dan sifat-sifat Tuhan yang tampak feminine (jamāl) dan maskulin (jalāl), atau dalam istilah Rūmī dengan istilah luthf dan qahr.

\section{Cinta dan Teofani dalam Waḥdat al-Wujūd}

Konsep teofani (theophany) atau pengejawantahan (tajallī) Tuhan pada mistikus muslim dipicu dari landasan normatif, yakni hadis yang secara tersirat mengatakan bahwa, "Aku adalah Khazanah Yang Tersembunyi, Aku senang untuk dikenal, maka Aku ciptakan makhluk'. ${ }^{11}$ Hadis ini dibahas sangat mendalam oleh Ibn 'Arabī (w.1240) yang hingga sekarang dikenal dengan konsep wahdat alwujūd-nya.

Dalam waḥdat al-wujūd, kosmos adalah teofani (pengejawantahan) Tuhan.Inti dari konsep ini mengatakan bahwa keragaman kosmos (alam) adalah satu (unity). Dengan kata lain, bahwa ide sentral waḥdat al-wujūd adalah,

Semua wujud adalah satu. ${ }^{12}$ Wujud tersebut adalah al-Haqq, tidak ada wujud lain, selain Dia. ${ }^{13}$ Entitas wujud adalah satu, tetapi hukumnya beraneka. ${ }^{14}$ Dia (al-Haqq/Tuhan) adalah esa dalam wujud, karena semua yang mungkin yang dapat dilihat, disifati dalam keadaan ini dengan ketiadaan.Semua yang mungkin itu tidak mempunyai wujud meskipun tampak bagi 
SUWITO: Relasi Cinta...

yang melihat.15Tidak ada keserupaan dalam wujud, dan tidak ada pertentangan dalam wujud, karena sesungguhnya wujud adalah satu realitas, dan sesuatu itu tidak bertentangan dengan dirinya sendiri. ${ }^{16}$

Kata wujūd digunakan oleh Ibn Arabī untuk menyebut wujud Tuhan.Satu-satunya wujud adalah wujud Tuhan; tidak ada wujud selain wujudNya. Dengan kata lain, apa pun selain Tuhan tidak mempunyai wujud. Kata wujud tidak dapat diberikan kepada selain Allah ( $m \bar{a}$ siwā Allāh).Meskipun demikian, Ibn 'Arabī juga memakai kata wujud untuk menunjukkan sesuatu selain Tuhan, tetapi dia menggunakannya secara metaforis untuk tetap mepertahankan bahwa wujud adalah milik Tuhan. Wujud yang ada pada $m \bar{a}$ siwā Allāh adalah wujud yang dipinjamkan. Sebagaimana cahaya hanya milik matahari yang dipinjamkan kepada penduduk bumi.Hubungan antara Tuhan dengan alam sering digambarkan serupa dengan cahaya dan kegelapan.Karena wujud adalah milik Tuhan, maka 'adam (ketiadaan) adalah "milik" makhluk. Karena itu, Ibn 'Arabī mengatakan bahwa wujud adalah cahaya, sedangkan 'adam adalah kegelapan. ${ }^{17}$

Bagi Ibn 'Arabī, menyebut tiga kategori wujud, 1) al-wujūd almuțlāq. Wujud mutlak, wujudnya wajib ada.Inilah Allah, 2) al-wujūd al-muqayyad, yakni sesuatu yang wujudnya karena diwujudkan. Adanya diwujudkan oleh Tuhan.Dia tidak memiliki wujud sendiri tetapi dari Tuhan.Inilah alam material dan segala yang ada di dalamnya, 3) posisi tengah-tengah antara kategori satu dan dua.

Berbicara kosmologi dalam kerangka pikir Ibn 'Arabī tidak akan lepas dari konsep al-Haqq dan al-khalq. Ada beberapa pengertian yang beragam dari beragam konteks. Di sini pengertian tersebut dibatasi pada konteks hubungan antara kedua konsep tersebut.

Al-Haqq adalah Allah, Sang Pencipta, Yang Esa, wujūd dan wājib al-wujūd. Sedangkan al-khalq adalah alam, makhluk, yang banyak, almaujūdāt dan al-mumkināt. Wujud dalam pengertian haikiki hanya

TEOLOGIA, VOLUME 25, NOMOR 2, JULI-DESEMBER 2013 
SUWITO: Relasi Cinta...

milik al-Haqq, segala sesuatu yang selain al-Haqq tidak memiliki wujud. Dengan demikian, wujud itu hanya satu yaitu al-Haqq.

Ibn 'Arabī mengatakan bahwa alam adalah penampakan diri (tajalli) al-Haqq. Segala sesuatu dan segala peristiwa alam adalah entifikasi (ta'ayyun) al-Haqq. Oleh karena itu, baik Tuhan dan alam, keduanya tidak bisa dipahami kecuali sebagai kesatuan antara kontradiksi-kontradiksi ontologis. ${ }^{18}$ Kontradiksi-kontradiksi tersebut tampak seperti Yang Tampak (al-ẓāhir) dan Yang Batin (albāțin), antara Yang Awal (al-awwal) dan Yang Akhir (al-ākhir), dan seterusnya.

Realitas adalah satu, tetapi mempunyai dua sifat yang berbeda, 1) sifat ketuhanan 2) sifat kemakhlukan.Sifat ketuhanan dan kemakhlukan hadir dalam segala sesuatu yang ada di alam. Dengan kata lain, dalam wujud hanya ada satu realitas yang dapat dipandang dari dua aspek yang berbeda. ${ }^{19}$

\section{Diskursus Maskulinitas (JalāI) dan Femininitas (JamāI) Tuhan dan Kosmos}

Pembahasan tentang Tuhan, seringkali "terhambat" dengan argumen normatif. Hal ini dapat dilihat beberapa hadis yang diriwayatkan oleh ibn Najjār dan al-Rāfi'i dari Abū Hurairah. ${ }^{20}$ Dalam polemik berkaitan pendiskusian Tuhan, Murata memberikan perspektif. Berkaitan dengan ini, ada dua perspektif penting, pertama, memahami Tuhan dengan mengesampingkan kosmos. Tuhan adalah Dia dalam Diri (Żat)-Nya. Dalam konteks ini, Tuhan tidak dapat dipahami siapapun. Dari sudut pandang ini seluruh pemikir muslim mengatakan bahwa Tuhan dalam Diri-Nya (Żat/Esensi), Tuhan tidak dapat dipahami. Perspektif ini mengantarkan kita pada konsep tentang tanzīh (ketakterbadingan) Tuhan.

Kedua, memahami Tuhan dengan sebagai penyebab munculnya kosmos, atau memahami Tuhan melalui kosmos (baik makro maupun mikrokosmos).Pemahaman ini mengantarkan kita pada konsep relasi antara Tuhan dengan kosmos.Dalam konteks ini, kita 
SUWITO: Relasi Cinta...

dapat menemukan sifat-sifat kosmos yang serba ganda, seperti baikburuk, tinggi-rendah, cinta-murka, kiri-kanan, depan-belakang, patuh-durhaka, pulang-pergi, lembut-keras, dan seterusnya. Kenyataan realitas yang ada pada kosmos ini jika dikaitkan dengan Tuhan (dalam teks-teks suciNya) ada unsur "kemiripan" dengan sifat-sifat (Sifāt) dan nama-nama (asmā) Allah. Dengan kata lain, ada "aspek ganda" dalam Tuhan. Dalam kaitannya dengan kosmos inilah para pemikir musli mencoba memahamiNya. ${ }^{21}$ Perspektif kedua ini dalam konsepsi Ibn 'rabī dinamakan tasybīh (keserupaan) Tuhan.

Ibn 'Arabī mencoba mengatasi blunder ini, dengan menekankan pemahaman tentang Tuhan pada perspektif kedua. Dengan cara demikian, tidak ada dasar normatif (hadis) yang dilanggar. Sekalipun sebagian muslim (terutama fuqaha) tetap menghindari spekulasi pemahaman ini.

Pembahasan "aspek ganda" ini sangat relevan di saat dunia disibukkan dengan gender mainstreaming oleh aktivis gender, yang mengampanyekan agar dunia bebas dan "keluar" dari dominasi kaum pria (maskulin). Pikiran dikhotomik pola Cartesian yang melihat segala sesuatu serba ganda ini menyebabkan segala sesuatu selalu dialektik dan bahkan bertentangan.Feminisme dan Ecofeminisme terlahir dari pola Cartesian ini.

Jika persoalan aspek dualitas semesta yang memiliki kemiripan pada Tuhan dikaitkan dengan isu gender era modern ini, maka kita dapat melihat dan menyebut kualitas-kualitas "gender" yang tampak dikhotomik pada al-asmā dan al-Sifäat Tuhan.

Dalam diskursus gender, femininitas dan maskulinitas adalah konsep kunci. Sifat-sifat atau kualitas seperti kelembutan, pelindungan, kasih sayang, keibuan seringkali diasosiasikan dengan femininetas (keperempuanan).Sementara keperkasaan, ketegasan, kekasaran, kebapakan seringkali dinisbahkan pada kualitas maskulin (kelakilakian).

TEOLOGIA, VOLUME 25, NOMOR 2, JULI-DESEMBER 2013 
Diskursus tentang aspek femininitas dan maskulinitas dalam sufi, telah lama dibicarakan. Konsep-konsep tersebut dapat dilihat pada Suhrawardi (w.1191), Ibn 'Arabī (w.1240), Rūmī (w.1273), alJandī (w.1300), al-Kāsyānī (w.1335). Pembahasan aspek feminitas dan maskulinitas ini mereka kaitkan dengan sifat dan nama-nama Tuhan kaitannya dengan kosmos.

Berbicara tentang aspek maskulinitas dan femininitas pada Tuhan, sama hal dengan berbicara tentang tasybih (keserupaan) Allah dengan kosmos. Sekalipun para sufi secara sadar mengakui ada perbedaan kualitas pada konsep tasybīh itu sendiri.

Konsep tasybīh ini tidak serta merta muncul dalam tasawuf, tetapi tema fundamental ini landasan pacunya memang disediakan oleh al-Quran dan hadis. Dalam landasan normatif, al-Quran dan hadis, dapat dijumpai kualitas-kualitas atau nama-nama atau sifat Allah seperti jalāl (keagungan), qahr (kekerasan), ghaghab (kemurkaan), ${ }^{22}$ sakht (kemarahan), ${ }^{23}$ kibriyā (kebesaran), qawī (kekuatan), dan masih banyak lainnya. Sementara kualitas feminine dapat dilihat seperti lutff (kelembutan), hubb (cinta), raḥim (kasih sayang), dan seterusnya.

Kualitas maskulin-feminin Ilahi menurut Ibn 'Arabī di antaranya adalah kemurkaan-keridhaan dan keagungan-keindahan. ${ }^{24}$ Sedangkan al-Jandī mengidentifikasi diantaranya adalah kemurkaankeridaan, keagungan-keindahan, kekerasan-kelembutan, mengambil-memberi. Menurut Murata, Jandī mengembangkan konsepkonsep Ibn 'Arabī terkait dengan konsep "tangan" Tuhan ini. ${ }^{25}$ Konsep polaritas "tangan” Tuhan Kāsyānī dalam prespektif gender sama dengan Ibn 'Arabī dengan perluasan jenis (bidang) polaritas. Selain gender (maskulin-feminin), Kāsyānī juga membahas polaritas "tangan" Tuhan dalam perspektif kosmos vis a vis Tuhan, "kualitas Tuhan vis a vis khalifah, serta kualitas khalfiah vis a vis kosmos.

Aspek jalāl dan jamāl Allah didiskusikan oleh Farghānī disaat membicarakan "Nafas" Tuhan (nafas al-Raḥmān).Dalam konteks ini 
SUWITO: Relasi Cinta...

dia mengatakan bahwa Allah berbicara, dan dalam nafas-Nya termanifestasikan kata-kata eksistensial, yakni makhluk-makhluk di alam semesta."Nafas" itu sendiri tunggal, tetapi dapat ditinjau dari beberapa tataran. Bagi Farghānī, "Nafas" ini kadang juga disebut dengan "entifikasi pertama", yakni munculnya wujud tercipta yang dapat dilihat. Pada proses ini dapat dilihat sifat dan kualitas yang berbeda. Namun, perlu diingat bahwa di luar "Nafas" tersebut terdapat Żat (Esensi) yang tak terbatas yang disebut "ke-Dia-an" (huwiyah) atau "Keghaiban seluruh keghaiban" (ghāib alghaib).MengenaiNya, tidak ada sesuatu yang positif sekalipun bisa ditegaskan.

Nama-nama Tuhan menurut Ernst dibagi menjadi dua, 1) Jalāl, nama yang merefleksikan kemuliaan, 2) Jamāl, nama yang merefleksikan keindahan. ${ }^{26}$ Nama-nama yang berkaitan dengan kemuliaan adalah kekuatan, murka, kuasa, dan keadilan.Sedangkan nama-nama yang berkaitan dengan keindahan seperti Maha Lemah Lembut, Maha Memberi, Maha Penyabar, dan Maha Pengampun. Bagi Ibn 'Ațā Allāh (w.1309), nama-nama tersebut sangat kuat pengaruhnya bagi pembaca. ${ }^{27}$

Bagi Rūmī Nama-nama dan Sifat-sifat Tuhan dibagi menjadi dua kategori, 1) Sifat-sifat dari Zat (Esensi), 2) Sifat-sifat dari perbuatan. Kategori pertama, Sifat-sifat apapun tidak layak dilekatkan pada Tuhan, seperti Hidup, Maha Melihat, Maha Kuasa dan seterusnya.Sifat-sifat ini memang selayaknya tidak disifatkan pada Zat Tuhan.Hal ini karena Tuhan memang tidaklah demikian. Dengan kata lain, Esensi (Źat) Tuhan tidak bisa dipahami sebagaimana sifat-sifat tersebut. Adapun kategori kedua adalah berkaitakan dengan namanama yang bertentangan tetapi juga merupakan Nama-Nya, seperti al-Mu'iz (Yang Maha Memuliakan), al-Mużill (Yang Maha Merendahkan), Yang Maha Memberi, dan Maha Mematikan, dan seterusnya. ${ }^{28}$

Kategori kedua ini (Nama-nama dari PerbuatanNya) dibagi menjadi dua, yakni 1) Sifat-sifat Kelembutan (Lutf), 2) Sifat-sifat Kekarasan (Qahr).

TEOLOGIA, VOLUME 25, NOMOR 2, JULI-DESEMBER 2013 
SUWITO: Relasi Cinta...

\begin{tabular}{|l|l|l|}
\hline \multirow{2}{*}{$\begin{array}{c}\text { Nama-nama } \\
\text { Zat }\end{array}$} & \multicolumn{2}{c|}{ Nama-nama Perbuatan } \\
\cline { 2 - 3 } & \multicolumn{1}{|c|}{ Nama-nama Qahr } & \multicolumn{1}{c|}{ Nama-nama Lutf } \\
\hline Raja & Yang Maha Memaksa & Yang Maha Lembut \\
\hline Suci & Merendahkan & Yang Maha memuliakan \\
\hline Adil & $\begin{array}{l}\text { Yang Maha } \\
\text { Menghinakan }\end{array}$ & Yang Maha Meninggikan \\
\hline Pelindung & Yang Maha Mematikan & Yang Maha Memberi \\
\hline Cahaya & Yang Maha Pembalas & Yang Maha Pengampun \\
\hline Pencipta & Yang Maha Pencabut & Yang Maha Kaya \\
\hline Hidup & $\begin{array}{l}\text { Yang Maha } \\
\text { Menghancurkan }\end{array}$ & Yang Maha Dermawan \\
\hline Kekuasaan & Yang Maha Menopang & $\begin{array}{l}\text { Yang Maha Luas } \\
\text { Mengetahui }\end{array}$ \\
\hline
\end{tabular}

Walaupun terdapat terdapat ketegori Nama (terutama Nama pada perbuatanNya), Allah sebagaimana hadiś qudsiNya mengatakan bahwa, "Kasih-Ku mendahului Murka-Ku" ${ }^{29}$

Menurut Rūmī, Nama-nama Lutf-Ku mendahului dan lebih diutamakan dari pada Nama-nama Qahr-Ku. Demikian juga, kasih, kesenangan, dan keindahan melekat pada setiap hambaKu dan merupakan sesuatu yang melekat secara inheren pad asetiap makhluk dan mendominasi seluruh bentuk yang notabene berasal dari Nama-nama dan Sifat-sifatNya. Dengan demikian, seluruh ciptaanNya mengejawantahkan Qahr dan Lutf-Nya.Namun, secara ontologism, yang kedua ( $L u t f$ mendahului Qahr).

Maskulinitas dan femininitas adalah istilah gender ${ }^{30}$ yang ini memang sering diasosiasikan dengan sifat laki-laki dan perempuan. Walau demikian, kunci memahami gender adalah bahwa sifat maskulin yang melekat pada laki-laki dan feminin yang melekat pada perempuan bukan bersifat permanen, tapi interchangeable. Sedangkan Rūmī dalam membicarakan konsep aspek femininitas dan maskulinitas merujuk pada istilah lutf dan qahr, yang polaritas pada kosmosnya tampak seperti ini berikut: 


\begin{tabular}{|c|c|}
\hline Lutf & Qahr \\
\hline Malaikat & Setan \\
Akal & Nasf \\
Surga & Neraka \\
Cahaya & Api \\
Adam & Iblis \\
Orang-orang suci & Orang-orang kafir \\
Agama & Kekafiran \\
Persatuan & Perpisahan \\
Keluasan & Kesempitan \\
Harapan & Ketakutan \\
Tawa & Airmata \\
Kesenangan & Kesusahan \\
Manis & Pahit, masam \\
Gula & Cuka \\
Musim panas & Musim dingin \\
Musim semi & Musim gugur \\
Siang & Malam \\
Bunga & Duri \\
Kesetiaan & Penghianatan \\
Anggur & Murni mabuk \\
Kemabukan & Ketenangan \\
Kemabukan & Sakit karena anggur \\
\hline
\end{tabular}

Sementara terkait dengan jalāl dan jamāl dalam konteks kosmos, pendapat Rūmī senada dengan Ibn 'Arabī yang mengatakan bahwa langit adalah pria, sementara bumi adalah perempuan. ${ }^{31}$ Dalam konteks ini, langit bersifat aktif, sementara bumi reseptif. Langit mencurahkan air hujannya, sementara bumi menerima curahan air dari langit.Dengan "perkawinan" kosmik tersebut kemudian bumi "melahirkan" berbagai macam potensi yang terkandung dalam "rahim" bumi. Dengan kata lain, langit adalah ayah, sementara itu bumi adalah ibu. Ibn `Arabī menjelaskan bahwa dengan pola kosmologi ini, para ayah dan para ibu-sifat-sifat langit dan sifat-sifat bumi-merupakan peralatan Tuhan untuk menciptakan alam raya manusia.Hal ini sebagaimana diketahui bahwa Ibn `Arabī mengatakan bahwa mikrokosmos adalah pusat wujud. Dengan kata lain, "miskrokosmos adalah kejayaan tertinggi dari kosmos". 32

TEOLOGIA, VOLUME 25, NOMOR 2, JULI-DESEMBER 2013 
Realitas, dalam hal ini kosmos bagi para sufi pastilah bipolar. Karena eksistensi suatu realitas tidak dapat dikenali kecuali ada oposisinya.Artinya, kiri tidak dapat dipahami kecuali ada kanan.Sifat baik tidak dapat dikatakan baik jika tidak ada yang buruk.Kenyataan inilah yang membedakan antara kosmos dengan Tuhan secara Esensial (Żat), yang dapat dipahami dalam tanpa "oposisi-Nya". Walaupun secara eksistensial, Ibn `Arabī mengatakan bahwa Tuhan dapat dikatakan Tuhan karena ada makhluk.

Konsep aspek femininitas dan maskulinitas pada Tuhan pada dasarnya adalah berawal dari sifat bipolar Tuhan yang telah disebut sendiri dalam firman suci-Nya. Dalam kosmologi sufi, sifat feminin adalah reseptif (menerima, pasif), sementara maskulin adalah aktif. Tuhan sebagai penyebab munculnya (aktif) kosmos adalah maskulin, sementara kosmos adalah feminin.Walaupun terdapat bipolar yang serba ganda dan berbeda keduanya tidak menjadi oposisi yang negatif yang selamanya bertentangan dan saling mendominasi. Bipolar dalam wacana sufi pada hakikatnya adalah sebuah kemestian karena cinta dan lokus cinta.

\section{E. Cinta Timbal Balik: Antara Tuhan dengan Kosmos}

Telah dikatakan di atas, proses manifestasi Tuhan dalam wujud eksistensi melahirkan bipolar. Dengan demikian, dalam wahdat alwujūd, bipolar adalah kemestian pada tataran eksistensial.Bipolar lahir karena cinta, dan dengan bipolar lahir cinta-cinta lain yang baru.Sebagaimana diketahui, bahwa diciptakannya alam karena cinta (keinginan, hasrat) Tuhan agar Dia dikenal.

Bagi Rūmī, Tuhan adalah mata air cinta. ${ }^{33}$ Hal ini karena Dia adalah sumber segala yang ada.Pemahaman bahwa Tuhan adalah Cinta, sebagaimana dipahami Rūmī dengan merujuk pada QS. 5: 54, "Tuhan akan mendatangkan suatu kaum yang Dia menyintai mereka dan mereka menyintai Dia”. Dalam konteks ini, ada cinta yang besifat timbal balik antara Tuhan dengan kosmos (manusia), bukan cinta bertepuk sebelah tangan. "Cinta adalah ikatan kasih-sayang, ia adalah sifat Tuhan". 
SUWITO: Relasi Cinta...

Sebagaimana Ibn `Arabī, bahwa alam diciptakan karena cinta Tuhan untuk mengetahui dirinya ( $f a$ ahbabtu an u'rafa fa khalaqtu al-khalqa). "Aku ingin (cinta) untuk dikenal, maka kuciptakan dunia. Bagi Rūmī, cinta adalah hasrat dan keinginan, sekalipun dalam Esensi Tuhan tidak dikenal hasrat dan keinginan. Sebagaimana dalam hadis qudsi yang sangat popular di dalam dunia tasawuf, Allah berfiman, "Jika bukan karena engkau, tidak akan Kuciptakan dunia".

Karena cinta, Tuhan kemudian "mengejawantahkan" Perbendaharaan Yang tersembunyi melalui diri nabi dan orang-orang suci yang menjadi motivasi penciptaan alam semesta.Sebagai hasilnya, Cinta Tuhan mengalir ke seluruh urat nadi kosmos. Bagi Rūmī seluruh gerakan berasal dari Cinta, bentuk-bentuk semesta tiada lain adalah pantulan-pantulan keunikan realitasnya. Karena seluruh yang ada mengambil bagian di dalam Cinta Tuhan, maka semua yang ada pada hakikatnya adalah para pecinta."Makhluk-makhluk bergerak karena Cinta".

Dalam konteks Luthf dan Qahr, Rūmī seringkali merujuk pada "pertentangan" antara malaikat versus setan. Pertentangan ini pada hakikatnya adalah pertentangan antara akal dan nafs.Rūmī seringkali menghubungkan nafs dengan sifat-sifat kebinatangan (keledai, anjing, babi, dan sapi) yang watak esksistensialnya adalah "kebuasan". Nafs tak pernah merasa puas, nafs birahi selalu menyuruhmu mengulang kembali, bagaikan anjing dan babi, seperti keledai dan sapi. ${ }^{34}$

Tuhan menciptakan malaikat dari akal murni dan menciptakan binatang dari nafs semata.Lalu Dia menempatkan akal dan nafs dalam diri manusia.Dengan demikian, akal manusia bersifat kemalaikatan, sementara nafs-nya bersifat kebinatangan. Menurut Rūmī, istilah "kebinatangan" identik dengan "kesetanan" dan "kejahatan". Iblis dan setan masuk ke dalam diri manusia melalui nafs dan menyatu dengannya. ${ }^{35}$

TEOLOGIA, VOLUME 25, NOMOR 2, JULI-DESEMBER 2013 
Nafs identik dengan iblis, dengan demikian ia identik dengan dunianya, yakni neraka, demikian juga sebaliknya, bahwa akal identik dengan malaikat dan surga. Pertentangan antara nafs dan akal, pada hakikatkanya adalah pertentangan antara api dengan cahaya. Dalam konteks ini, dapat dilihat bahwa pengejawantahan sifat Luthf dan Qahr secara konsepsional tampak berlawanan antar keduanya. Drama pertentangan antara api dengan cahaya, iblis dengan malaikat, pendosa dengan orang-orang suci, neraka dengan surga secara konsepsional berasal dari dua Sifat Yang Tersembunyi. Setiap pasangan pertentangan merupakan suatu keniscayaan bagi eksistensi dunia dan sebagai pengejawantahan Perbendaharaan Yang Tersembunyi. Bagi Rūmī, "sesuatu akan menjadi jelas karena ada pertentangan".

Kedua hal yang bipolar yang berbeda dan saling beroposisi tersebut merupakan medan permainan yang jelas bagi manusia. Bipolar dalam hadis adalah wujud rahmat (kasih sayang) Tuhan. ${ }^{36}$ Keselarasan kedua sifat (Luthf dan Qahr) tidak hanya ada pada eksistensi kosmologis, tetapi juga ada pada prilaku dan pengalaman eksistensial manusia. Sekalipun terdapat konsepsi yang bertentangan, prinsip yang selalu dikemukakan oleh para sufi termasuk Rūmī adalah, bahwa "Kasih Tuhan mendahului murka-Nya".

Dalam melukiskan relasi cinta Tuhan dengan kosmos, terutama terkait ide tentang manusia (mikrokosmos) sebagai tujuan akhir penciptaan kosmos, Rūmī menjelaskan dengan sangat apik.Rūmī menggunakan metafor buah dan pohon untuk menjelaskan ide ini. Bagi Rūmī, pemikiran tentang buah adalah awal, sekalipun realiasasi (aktualnya) jatuh di akhir seluruh proses. Di saat seorang petani memikirkan buah tertentu, maka yang harus direalisasikan sebelumnya adalah lahan (tanah) yang subuh untuk menanam, bahkan sistem pengairan, atau infrastruktur yang harus dipenuhi untuk "calon" buah yang dikehendaki. Setelah menyiapkan lahan, petani kemudian mengakualkan pohon.Akar, ranting, daun, cabang, bunga adalah awal.Namun tujuan akhirnya adalah buah. ${ }^{37}$ 
SUWITO: Relasi Cinta...

Petani yang baik adalah petani yang merawat dengan tanaman yang menjadi bakal buah dengan kasih sayang.Dia memberi pupuk, menyiangi, membuang penyakit, memberi cukup air, dan seterusnya sebagai wujud kasih sayang terhadap tumbuhan yang buahnya dia cita-citakan.

Dalam konteks coindencitia oppositorum petani berbeda dengan tanaman. Ini dapat dilihat dari peran yang dimainkan.Petani bersifat aktif, sementara tanaman tersebut bersifat pasif (reseptif).Petani adalah penaman (pembuat), sementara ditanam (dibuat).Petani adalah yang pertama, sementara tanaman kedua. Dalam konteks feminine-maskulin dalam wacana sufi, petani adalah maskulin, sementara tanaman adalah feminin.

Dalam konteks yang lebih besar cakupannya, lahan, akar, ranting, daun, cabang adalah "makrokosmos", sementara buah adalah "mikrokosmos", petani adalah metakosmos. Dalam "diri" buah yang mikro ini meliputi seluruh eksistensi makrokosmosnya.Di dalam buah terdapat biji yang secara potensial dapat berkembang menjadi akar, daun, ranting, cabang, bunga, dan bahkan buah.

Metafor tersebut dapat memberikan penjelasan tentang relasi cinta antara aspek maskulinitas dan femininitas dalam Tuhan dan alam. Dengan kata lain, aspek femininitas dalam hal ini adalah penyebab lahirnya sesuatu, termasuk lahirnya nama-nama Tuhan yang dapat dikenal. Aspek feniminitas mendorong dan menginspirasikan maskulinitas untuk mewujudkan cinta-cintaNya. Dengan kata lain, tanpa aspek femininitas, maskulinitas tidak akan aktif.

Konsep ayah dan ibu secara kosmologis adalah perantara kelahiran "sang buah" hati. Dalam konteks penciptaan setelah Adam, buah hati akan lahir dengan perantaraan ayah dan ibu. Dalam konteks relasi antara anak (buah hati) dan kedua orang Kāsyānī menjelaskan tafsir QS.al-Isra [17]:23-24. Dia mengatakan bahwa Allah menempatkan berbuat baik setelah tauhid.Dengan konsep

TEOLOGIA, VOLUME 25, NOMOR 2, JULI-DESEMBER 2013 
SUWITO: Relasi Cinta...

tauhid mengeaskan bahwa hanya Tuhan yang layak disembah. Orang tua dalam hal ini berhubungan dengan Kehadiran Ilahi dengan kenyataan bahwa Dia adalah penyebab eksistensi sang buah hati. Orang tua juga berhubungan dengan kehadiran Ilahi berkaitan dengan pemeliharaan buah hati saat masih bayi dan dalam keadaan lemah. ${ }^{38}$

Dalam membahas ini, Ibn 'Arabī dan pengikutnya mengaitkannya dengan istilah perkawinan. Buku yang membahas secara detail ini adalah Kitāb al-Nikāh al-Sārī fi Jāmi' al-Ḍarārī, yang dinyatakan Murata ${ }^{39}$ sebagai kitab yang hilang (belum ditemukan keberadaannya). Walau demikian, dalam isi kitab ini juga dibahas dalam Futuhăt. Dalam konteks ini Ibn 'Arabī mengatakan bahwa ilmu tentang interprenetrasi (tadākhul) mencakup banyak hal.la merupakan ilmu penghubung (iltihām) dan "perkawinan". Ada tiga jenis "penghubung" dan "perkawinan", 1) indrawi, 2) supra-indrawi, 3) ilahiyah. Ibn 'Arabī menjelaskan bahwa perkawinan indrawi terajadi pada hewan dan manusia, sementara yang supra-indrawi adalah perkawinan atau penghubung yang berkaitan dengan penggabungan ide-ide atau logika silogisme dari premis-premisnya.Sedangkan "perkawinan ilahiyah" berkaitan antara Dia dan benda non-eksisten dan eksisten. Dia dan benda yang non eksisten disebut dengan Ayah dan ibu, sementara benda eksisten yang merupakan hasil dari penyatuan disebut "anak". Bagi Ibn 'Arabi, tanpa "perkawinan ilahiyah" ini Harta yang Tesembunyi tetapi tersembunyi.

Dalam memahami QS.Ali Imrān [3]: 6, ${ }^{40}$ Ibn 'Arabī menguraikan kata arḥām (rahim-rahim) dalam makna imajinal. Tuhan membentuk benda-benda imajinal dalam rahim-rahim sesuai dengan kehendaknya atas dasar "perkawinan" supra-indrawi, dan "kehamilan" supra-indrawi.Dari rahim-rahim inilah kemudian melahirkan bentuk-bentuk. ${ }^{41}$

Pemahaman gender (maskulinitas dan femininitas) dalam wacana sufi memperjelas pada kita pada konsep tentang cinta, baik secara ontologi, epistemologi, dan aksiologinya. Maskulinitas dan 
SUWITO: Relasi Cinta...

femininitas adalah sebab sekaligus akibat cinta. Walaupun demikian, femininitaslah yang menginspirasi munculnya maskulinitas dan kreasi-kreasi lain. Kreasi ini dalam konteks ketuhanan diorientasikan pada femininitas. Dalam hal ini, Ibn 'Arabī mengurai "misteri kekuatan" wanita dengan mengatakan bahwa tanpa wanita, pria bukanlah seorang pria, karena pria didefinisikan oleh wanita. Sementara itu, dalam konteks kosmos dengan Tuhan dia mengatakan bahwa keberadaan kosmos membuat yang Nyata menjadi Tuhan. ${ }^{42}$

Relasi yang harmonis ini dapat memberikan landasan baru terkait dengan penting terkait dengan moral building berdasarkan pemahaman terhadap Tuhan dan kosmologi sufi. "Moral/etika baru" ini kemudian menjadi pilar penyangga kehidupan yang harmoni dengan mengedepankan relasi berdasarkan cinta, bukan murka. Sumbangan etika sufi ini kemudian dapat mereduksi nafsu hegemoni dan dominasi yang merupakan benih ketidakharmonisan.

\section{F. Penutup}

Dalam wacana sufi, cinta adalah salah satu sifat yang dikategorikan dalam kualitas feminin (jamāl). Sementara itu, dalam kehidupan sosial modern saat ini, terutama pada diskursus gender, femininitas dan maskulinitas seringkali dibenturkan, sehingga dalam istilah Marx terjadi "pertentangan kelas/struktur".

Dalam tradisi sufi terutama dalam tasawuf waḥdat al-wujūd, dengan menggunakan pola pikir imaginal thinking melihat dan memahami dualitas (bipolar), bahkan keragaman sekalipun ini adalah unity of opposites. Dalam konteks sufi, maskulinitas-yang dinyatakan yang secara sosiologis dinyatakan dominan itu-secara substansial memiliki "kelemahan". Karena maskulinitas tidak akan muncul jika tidak ada femininitas. Sementara dalam konteks lahirnya wujud semesta dan apapun yang ada justru lahir karena dorongan cinta yang masuk pada karegori feminin ini. Dengan kata lain, maskulinitas tidak akan lahir jika tidak didorong oleh aspek feminin.

TEOLOGIA, VOLUME 25, NOMOR 2, JULI-DESEMBER 2013 
SUWITO: Relasi Cinta...

Inilah "misteri kekuatan dahsyat" aspek femininitas dalam wacana sufi. Dengan demikian, tidak ada yang lebih superioritas antara dua aspek ini.Relasinya adalah setara berdasar dan akibat dari cinta. [

\section{Catatan Akhir}

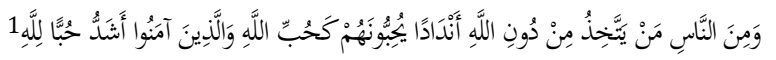

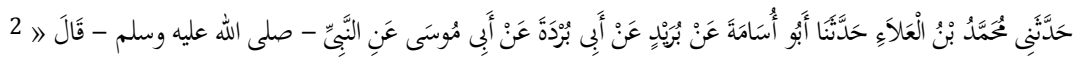

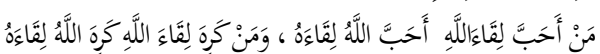

Lihat al-Bukhārī, Sahịḥ Bukhārī, Jil. XXI, Mesir: Mauqi' Wazārah wa alAuqāf al-Mișiriyah, t.th, h. 401.

${ }^{3}$ AbūHāmid al-Ghazālī, Ihyā 'Ulūm al-Dīn, Juz III, dalam Maktab alSyāmilah, CD Software, h. 85.

Lihat Mahmūūd al-Alūsī Abū Faḍl,

Rūḥ al-Ma'ānī fi Tafsīr al-Qur'ān al-'Azīmwa Sab'u al-Maśānī, Juz XIII, Bairut: Dār Ihyyā al-Turās̀ al-'Arābī, TT, h. 10. Hadis̀ ini dinyatakan Șaḥịholeh para sufi, tetapi ahli hadis memberikan penilaian yang sebaliknya.

${ }^{5}$ Menurut Michael A. Sell, catatan paling lengkap terkait dengan ucapan-ucapan Rābi ah al-Adawiyah yang berisi konsep-konsep mahabbahnya dapat ditemui pada Farīd al-Dīn Atțār (w. 1230), dalam Tażkīrāt alAuliyā.Lihat Sell, Sufisme Klasik, Bandung: Mimbar Pustaka, 2003, h. 223225, Lihat juga Julian Baldick, "The Legend of Rabi'ah of Bașra: Christians Antecedents, Muslim Counterparts", Religion 20, 1990, h. 233-247.

6Jalāl al-Dīn Rūmī lahir di Balkh, Afghanistan pada 604 H/1207 M. Meninggal pada $672 \mathrm{H} / 1273 \mathrm{M}$.

7 William C. Chittick, Jalan Sang Sufi, Jogjakarta: Pustaka Qalam, 2003, h. 292. Mei 2009.

${ }^{8} \mathrm{http}$ ///en.wikipedia.org/wiki/Unity_of_opposites, Download, 25

${ }^{9}$ Edward Craig, Routledge Encyclopedia of Philosophy: Sociology of knowledge to Zaroastrianism, Routledge: Taylor \& Francis, 1998, h. 437.

${ }^{10}$ Dua cara berpikir ini dapat dibaca dalam Toshihiko Izutsu, "Ishraqiyah," The Encyclopedia of Religion, diedit oleh Mircea Eliade, 16 volume, New York: Macmillan, 1987, Vol. VII, h. 296-298; William C. Chittick, "Sufi Thought and Practice", The Oxford Encyclopedia of the Modern IslamicWorld, diedit oleh John L. Esposito, 4 volume, New York \& Oxford: Oxford University Press, 1998, Vol. IV, h. 105-106; Daniel J. Adams, Cross Cultural Theology: Western Reflections in Asia, New York: John Knox Press, 1987. 
${ }^{11}$ Michael A. Sell, Sufisme Klasik, h. 223-225; Julian Baldick, "The Legend of Rabi'ah of Bașra...", h. 233-247.

${ }^{12} \mathrm{Ibn}$ 'Arabī, Kitāb al-Jalālah, dalam Rasāil Ibn al-Arabī, Part 2, Heydarabad-Deccan: The Dairat al-Ma'ârif al-Osmania, 1948, h. 9; lihat Kautsar Azhari Noer, Ibn al-Arabī, h. 35, 145.

13Ibn 'Arabī, al-Futuhāt al-Makkiyah, Jil. II, Kairo: Dār al-Kutub al'Arābiyah al-Kubrā, 1329/1911, h. 516. Lihat Kautsar Aẓari Noer, Ibn alArabì, h. 35.

14Ibn 'Arabī, al-Futuhāt, Vol. II, h. 519.

15Ibn 'Arabī, al-Futuhāat, Vol. III, h. 290.

16Ibn 'Arabī, Fușūs al-Hikam, diedit dan diberi komentar oleh Abū alA'lā 'Afífì, Vol. I, Beirut: Dār al-Kitāb al-'Arābī, 1980, h. 90.

17Ibn 'Arabī, al-Futuhāt, Vol. II, h. 486; Vol. III, h. 274, dan Vol. IV, h. 39.

${ }^{18 K e s a t u a n}$ antara pertentantangan-pertentangan, al-jam' bayn alAddād atau kesatuan antara dua pertentangan , al-jam' bayn al-diddāyn yang di dalam filsafat Barat disebut dengan coincidentia oppositorum. Lihat Kautsr Azhar Noer, Ibn Arābī, h. 49.

19Ibid., h. 50.

${ }^{20}$ Jalāl al-Dīn al-Suyūțī, Jam'u al-Jawāmi' aw al-Jāmi` al-Kabīr li alSuyūtī, Juz I, tt: tp, tth, h. 11085. Hadis yang berbunyi تفكَّوا فن خلق الله ولا تفكروا فن الله ini tidak ditemukan pada Bukhārī maupun Muslim serta kitab sunan yang lain. Hadis serupa dengan lafaz yang berbeda dapat ditemukan pada Țabranī, Mu'jam al-Kabïr. Juz XI , tt: tp, tth, h. 313.

${ }^{21}$ Murata, TheTao of Islam, h. 79.

${ }^{22}$ QS. al-Fātiḥah [1]: 7.

23Sachiko Murata, The Tao of Islam, terj. Rahmani Astuti, Bandung: Mizan, 1996, h. 103.

${ }^{24}$ Ibn 'Arabī, Fușuṣ al-Hikam, diedit oleh Afïfi, Beirut: Dār al-Kutub al'Arabī, 1946, h. 55-56.

25Murata, The Tao of Islam, h. 135.

${ }^{26}$ Carl W. Ernst, Ajaran dan AmalanTasawuf, Jogjakarta: Pustaka Sufi, 2003, h. 121.

27Ibn 'Ațā Allāh al-Sakandarī, Miftāh al-Falāh wa Miṣbāh al-Arwāḥ, Mesir: Mațba'ah Muștafā al-Bābī al-Ḥalabī wa Aulāduh, 1961, h. 34-36.

28 William C. Chittick, Jalan Cinta Sang Sufi: Ajaran Spiritual Jalaluddin Rumi , Jogjakarta: Penerbit Qalam, 2003, h. 64. 


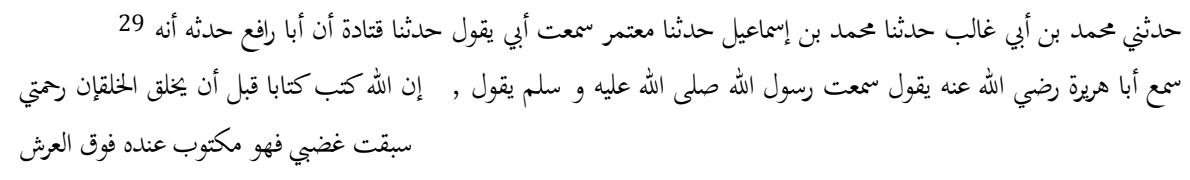

Muhammad ibn Ismāīil Abū ‘Abd Allāh al-Bukhārī al-Ja'fĩ, Șahịḥ alBukhārī, Juz VI, Bairut: Dār Ibn Kas̄īr, 1987, h. 2745; bandingkan dengan teks Muslim al-Hajjah Abū al-Ḥusain al-Qusyairī al-Naisaburī, Ṣaḥị̣ Muslim, Juz IV, Beirut: Dār al-Turaś al-'Arābī, tth, h. 2107.

${ }^{30}$ Istilah gender berbeda dengan jenis kelamin. Gender adalah konstruk sosial, sementara jenis kelamin adalah bawaan, kodrat. Gender bersifat tidak permanen, interchangeable dapat dipertukarkan, sementara jenis kelamin bersifat permanen. Lihat Oakley Ann, Sex, Gender, and Society, New York: Harper and Row, 1972; Imam Kanafi, Metafiasika Sufi dan Relasi Gender: Sebuah Studi atas Pemikiran Suhrawardi Syaikhul Isyrāqiyah, Jakarta: SPs. UIN Jakarta, 2008, h. 26-28.

31Murata, The Tao of Islam, h. 197.

32Ibid., h. 199.

33 William C. Chittick, Jalan, h. 293.

34Ibid., h. 128.

35Ibid., h. 129.

36Jalāl al-Dīn al-Syuyūthī, Jam'u al-Ahādiś, Jil. II dalam Maktabah Syāmilah, CD, h. 40.

37William C. Chittick, Jalan, h. 95; Lihat: Jalāl al-Dīn Rūmī, Mathnawi, Jilid II, Syair nomor 970-974.

38‘Abd al-Razzāq Kāsyānī, Ta'wīlāt, Juz I , Beirut: Dār Yaqzât alAdabiyat, 1968, h. 717

${ }^{39}$ Murata, The Tao of Islam, h. 202.

41 Ibid.,h. 204.

42Ibid., h. 254. 


\section{DAFTAR PUSTAKA}

Abū Faḍl, Maḥmūd al-Alūsī, Rūḥ al-Ma'ānī fi Tafsīr al-Qur'ān al'Azìimwa Sab'u al-Maśānī, Juz XIII, Bairut: Dār Ihyāa al-Turās̀ al'Arābī, tth.

Adams, Daniel J., Cross Cultural Theology: Western Reflections in Asia, New York: John Knox Press, 1987.

Ann, Oakley, Sex, Gender, and Society, New York: Harper and Row, 1972.

Baldick, Julian, "The Legend of Rabi'ah of Bașra: Christians Antecedents, Muslim Counterparts", Religion20, 1990, h. 233247.

Bukhārī, Șạ̣ịh Bukhārī, Jil. XXI, Mesir: Mauqi' Wazārah wa al-Auqāf al-Mișiriyah, t.th, h. 401.

Chittick, William C., "Sufi Thought and Practice", The Oxford Encyclopedia of the Modern IslamicWorld, diedit oleh John L. Esposito, 4 volume , New York \& Oxford: Oxford University Press, 1998.

Chittick, William C., Jalan Cinta Sang Sufi: Ajaran Spiritual Jalaluddin Rumi , Jogjakarta: Penerbit Qalam, 2003.

Chittick, William C., Jalan Sang Sufi, Jogjakarta: Pustaka Qalam, 2003.

Craig, Edward, Routledge Encyclopedia of Philosophy: Sociology of knowledge to Zaroastrianism, Routledge: Taylor \& Francis, 1998.

Ernst, Carl W., Ajaran dan AmalanTasawuf, Jogjakarta: Pustaka Sufi, 2003.

Ghazālī, AbūHāmid, Ihyyā 'Ulūm al-Dīn, Juz III, dalam Maktab alSyāmilah, CD Software.

http://en.wikipedia.org/wiki/Unity_of_opposites, Download, 25 Mei 2009.

Ibn 'Arabī, al-Futuhāt al-Makkiyah, Jil. II, Kairo: Dār al-Kutub al'Arābiyah al-Kubrā, 1329/1911.

TEOLOGIA, VOLUME 25, NOMOR 2, JULI-DESEMBER 2013 
Ibn 'Arabī, Fușūṣ al-Hikam, diedit dan diberi komentar oleh Abū alA'lā 'Afífì, Vol. I, Beirut: Dār al-Kitāb al-'Arābī, 1980.

Ibn 'Arabī, Fușuṣ al-Hikam, diedit oleh Afífi, Beirut: Dār al-Kutub al'Arabī, 1946.

Ibn 'Arabī, Kitāb al-Jalālah, dalam Rasāil Ibn al-Arabī, Part 2, Heydarabad-Deccan: The Dairat al-Ma'ārif al-Osmania, 1948.

Imām Bukhārī, Muhạmmad ibn Ismā'īl Abū ‘Abd Allāh, Saḥịh alBukhārī, Juz VI, Bairut: Dār Ibn Kasīir, 1987.

Imām Muslim, Abū al-Husain Muslim bin al-Hajjaj al-Qusyairī alNaisaburī, Șahịḥ Muslim, Juz IV, Beirut: Dār al-Turaś al-'Arābī, tth.

Izutsu, Toshihiko, "Ishraqiyah," The Encyclopedia of Religion, diedit oleh Mircea Eliade, 16 volume, New York: Macmillan, 1987.

Kanafi, Imam, Metafiasika Sufi dan Relasi Gender: Sebuah Studi atas Pemikiran Suhrawardi Syaikhul Isyrāqiyah, Jakarta: SPs. UIN Jakarta, 2008.

Kāsyānī, Abd al-Razzāq, Ta'wīlāt, Juz I, Beirut: Dār Yaqẓat al-Adabiyat, 1968.

Murata, Sachiko, The Tao of Islam, terj. Rahmani Astuti, Bandung: Mizan, 1996.

Rūmī, Jalāl al-Dīn, Mathnawi, Jilid II, Syair nomor 970-974.

Sakandarī, Ibn 'Ațā Allāh, Miftāḥ al-Falāḥ wa Miṣbāḥ al-Arwāḥ, Mesir: Maṭa'ah Muștafā al-Bābī al-Halabī wa Aulāduh, 1961.

Sell, Michael A., Sufisme Klasik, Bandung: Mimbar Pustaka, 2003.

Suyūthī, Jalāl al-Dīn, Jam'u al-Ahạdisis, Jil. II dalam Maktabah Syāmilah , CD.

Suyūṭī, Jalāl al-Dīn, Jam'u al-Jawāmi' aw al-Jāmi` al-Kabīr li al-Suyūṭī, Juz I, tt: tp, tth.

Țabranī, Mu'jam al-Kabìr. Juz XI , tt: tp, tth. 